\title{
Islamism and Secularism: Between State Instrumentalisation and Opposition Islamic Movements
}

\author{
Islah Jad
}

Abstract In Palestine, a reassertion of the 'secularist' identity of the 'Palestinian national project' is taking place against a deeply divided political society characterised by a Palestinian authority in conflict with Hamas. This article argues that the instrumentalisation of religion by the state has backfired leaving secular feminist activists in an unenviable position - without a constituency or a socially legitimate framework through which to address gender and social justice issues. At the same time, a reassertion of the 'secularist' identity is taking place against a deeply divided political society characterised by a Palestinian authority in conflict with Hamas. This conflict accompanying the 'secularisation process' resulted in crushing the very structure of the notion of citizenship and the figure of the secular citizen subject itself.

\section{Introduction}

To counter the Hamas 'threat to the occupied West Bank' (Palestine), the Palestinian Awqaf (Islamic Endowments) Minister issued a statement on 10 September 2010 banning Eid lullabies after Ramadan, calling the practice bid'a (an invention). That stand was preceded by another move led by the Palestinian authority, in its bid to contain and weaken the Islamist movement Hamas: enforcing control over the mosques in order to limit the role of the religion in daily life, and cancelling the Qur'an reading before the call for prayer or the use of loud speakers. This new policy stresses the 'secularist' identity of the 'Palestinian national project' under President Mahmoud Abbas and his Prime Minister Salam Fayyad and is supported by all political factions under the umbrella of the Palestine Liberation Organisation (PLO). It replaced Yasser Arafat's policy that tried to coopt the Islamic movement and push his own image as a Jihad fighter. Arafat's famous call 'to march to Jerusalem with millions of martyrs' in 2004 , is a remnant of this. What brought about this change in the stance of the Palestinian leadership from that of Jihadi Muslims to staunch secularists? Why do some prominent leaders publicly advocate that 'faith should not intervene in politics' to safeguard the
'Palestinian national project and building a Palestinian state'?

This article argues that the Palestinian national elite have not suddenly discovered a 'true secular' identity triggering this change in their political outlook. Rather, post-colonial 'secularist' nationalist elites in the Arab world started using religion in this way long before contemporary Islamic movements came on the scene. The result of this 'secularisation' process in the Arab world, we are now witnessing, is a decaying police state in which all sorts of rights (political, civil and social) are systematically violated.

The important point to make here is that if we compare the trajectory of secularism - a term born in the West - with how it developed in Arab societies, the focus of the analysis is not on its origins but on the forms of life secularism articulates, the powers it releases or disables. It then becomes increasingly clear that Arabic secularism resulted in crushing the very structure of the notion of citizenship and the figure of the secular citizen subject itself.

2 The state debate: beyond secularism vs religion Historically, ${ }^{1}$ the newly formed Arab nationalist governments co-opted and adapted religion for

IDS Bulletin Volume 42 Number 1 January 2011 @ 2011 The Author. IDS Bulletin (? 2011 Institute of Development Studies Published by Blackwell Publishing Ltd, 9600 Garsington Road, Oxford OX4 2DQ, UK and 350 Main Street, Malden, MA 02148, USA 
their own political ends. Secularism - a separation between religion and state - thus did not take root in Arab states. The portrayal of Islam as a threat to secularism betrays the fact that the relationship between the state, religion, society and politics is far more intertwined, in the Palestinian case, than is often portrayed. I concur with Asad's approach (2003) of not adapting an analytical approach of dichotomised realities of the secular vs the religious. A more nuanced approach would be to examine the historical circumstances around which secular political projects or Islamist counterparts are promoted. Arab nationalism, as adapted by Baathist, Nasserist or other regime types, incorporated Islam as part of its claims of difference vis-à-vis other socialist ideologies; it was a unifying ideology in the quest for building what Salame (2001) calls, 'a state of legitimation' (a source of legitimacy), deriving strength from enduring social elements, rather than insisting more fundamentally on change and innovation. AlAzem (2004) goes further and accuses 'secular' nationalist elites of obstructing a rational understanding of Islamic cultural heritage so that it instead became the subject of independent social science research - an ideological tool in the service of elite regional, national or party politics. So when the nationalist waves faded away, the uncritical approach to Islam and Islamic heritage remained and was easily presented as an untouchable core of Arab and Muslim identity.

In analysing the fluctuating relationship between Islam as a religion and nationalism as a secular notion, Lawrence (1987) explains that Islamism was shaped by the overwhelming and new character of 'secularisation'. This not only permeated the elite classes of Muslim countries but permanently affected everyone living in the Muslim world through the emergence of new institutions of communications, healthcare, education and above all nationalism itself, which claimed to 'construct' new citizens. Lawrence propounds the idea that, while nationalism was not originally a Muslim institution, it was adopted by Muslim elites as a strategy for coping with the otherwise intractable authority of colonial governments, economies and armies. In this context, what emerged within nationalism in nearly every country, including Egypt, was an enforced obedience to the state, with the kind of Islam advocated by the government made compulsory as a symbol of political loyalty and religious orthodoxy (Lawrence 1987: 29). Thus, Islam was amalgamated with Arab secularism from its inception. ${ }^{2}$

Turning to the Palestinian case, it is argued here that the brand of Islamic movement contesting the power of the Palestinian national movement is a product of the failure of the secular national movement to deliver on its promises of national independence or state building. One of the elements that eased the shift to a 'fusion' between Islam and Palestinian nationalism was the defeat of the Palestinian national movement and the ability of Hamas to identify itself with the struggle to gain Palestinian national rights.

Analysing the ideology of the political party Fateh, as the backbone of the PLO and contemporary nationalist movement, AbdelJawad (2003) states that Islam as a religion was never put aside by Fateh leadership. In his study of the subject, Abdel-Jawad reveals that the majority (13 out of 21) of the founding leaders of Fateh in the early 1950s were either members of the Muslim Brothers, the Islamic Liberation party, or sympathisers (Abdel-Jawad 2003). Fateh's first magazine, Falastinuna (Our Palestine), reflected the religious language and orientation of the nascent movement which, according to Abdel-Jawad, helped spread the movement's agenda among refugees in Gaza who came from rural, conservative backgrounds. Among the old elite of Fateh, Christians represented 20 per cent (although their presence did not exceed 11 per cent) and all the founding leaders were Muslims. As for the secular PLO, Fateh always made extensive use of common Islamic concepts such as jihad (holy war) and shahid (martyr). The Marxist Palestinian movements never had anything like the popular appeal of Fateh. It is legitimate to point out here that the PLO's discourses on modernity were conditioned not only by the encounter with Zionism, but also by its troubled relations with different Arab regimes - using a more conservative and religious approach with the Saudis for example, more liberal and 'modern' with the Tunisians, and 'progressive' and 'modern' with the then Soviet Union.

One of the diagnostic criteria for unmasking the nature of a national project is to examine its construction of gender and gender relations. Many writers and scholars, however, who have 
written on Hamas and Palestinian nationalism (Hroub 1996, 2000; Abul-Omrein 2000; Abu

'Amr 1994) are silent on this question.

Those authors who insist Palestinian national identity was mainly based on secular idioms homogenise this identity; they refuse to see how nationalism and its multiple identities are permeated by class, gender and religion (Anthias and Yuval-Davis 1989; Kandiyoti 1991).

Kandiyoti, for example, demonstrates that 'although many [nationalisms] were influenced by the ideas of the enlightenment and were of secular persuasion, they unwittingly endorsed the notion that any changes in the position of women could only be condoned in the national interest' (Kandiyoti 1991: 410). Nationalist ideologies need an 'ideal woman' but she is ambiguous. Fateh perceived gender relations and the 'ideal woman' as carrying, as Kandiyoti puts it, 'their own ambiguities and tensions' (Kandiyoti 1998: 282). The 'ideal woman' was portrayed as the peasant, the fertile, modest and 'authentic'. However, at the same time, 'the modern woman' was portrayed as the disciplined, with a de-eroticised body, the 'sister of men'. In other words, the Palestinian national movements portrayed women as the 'privileged repository of uncontaminated national values' (Kandiyoti 1991: 410). The parallel models of woman have persisted through Fateh, the PLO and the Palestinian National Authority (PA).

Fateh always resisted challenging the patriarchal control of women within the PLO. The many attempts by activists in the General Union of Palestinian Women to promote and protect women's rights in divorce, marriage and inheritance, failed. The activists attributed this failure to the refusal of the head of the PLO to endorse any such move or, according to Khaled and Salah (personal interview, 2003), 'to question the flagrant abuse and exploitation of some of the Fateh fighters whether in the uncontrolled practices of polygamy, the failure to recognise their children from undeclared marriages, or the many cases of domestic violence'.

This might serve to explain the ease with which support for a secular PLO, comprising of men and women, was transformed into sympathy for, and, in many cases, even allegiance to, the Islamic movement. The increasing politicisation of gender and religious identities might call into question the 'progressiveness' of the secular Palestinian national unity and the unity of the Palestinian national identity.

\section{The state instrumentalising religion, demobilising political Islam}

In the Arab world, the fusion of religion and nationalism as a brand of 'secularism' wielded among the post-colonial national elites was a clear marker of identity for these post-colonial nation-states. Writing on Islamism and secularism, Hermassi (1993), for example, summarises the differences in the important distinction between de facto and de jure secularism. Whereas in the West de jure secularism called for the formal separation of the church and state, the Arab state recognised Islam as the religion of society, but de facto demobilised its political use.

Further conflict may be noted between Islam as a religion and nationalism. In contemporary political Islamic movements, the 'new' meaning of Islam includes all Muslims but excludes nonMuslims, unlike nationalism. But like nationalism, Islam is also interpreted as a political system and used for political ends, which is a threat to secularism (Al-Azmeh 1996; Roy 1999). However, according to Asad (2003), both Arab nationalism and Islamism share a concern with the modernising state because Islamism takes for granted and seeks to work through the nation-state, which is so central to the predicament of all Muslims. It is this statist project, he argues, and not the fusion of religious and political ideas that gives Islamism a 'nationalist' cast. Asad urges us not to focus on the 'real motives' of Islamists, but rather to look for what circumstances oblige 'Islamism' to emerge publicly as a political discourse, and how it challenges the deep structures of secularism. He stresses interconnections between religion and secularism by stating:

... although religion is regarded as alien to the secular, the latter is also seen to have generated religion, that in the pre-modern past secular life created superstitious and oppressive religion and in the modern present secularism has produced enlightened and tolerant religion. Thus, the insistence on a sharp separation between the religious and the secular goes with the paradoxical claim that the latter continually produces the former. (Asad 2003: 193) 
Examining the Palestinian case in the light of the above insights, it can be said that the current entrenchment presented as a conflict between 'dark forces' and 'enlightened forces' is not merely a veneer for deep and divergent political agendas. They diverge over what path should be followed to realise an independent Palestinian state, the path of national struggle advocated by Hamas or peace negotiations as advocated by the PA. This political diversion took a violent path through the indoctrination process of the Palestinian security forces as they cracked down on Islamists to 'protect the national project'. This process perceives Islamists as aliens rather than part of the Palestinian polity, thus allowing serious violation of rights whether political, civic or social.

The witch hunt against Islamists led them to use force to protect their presence and take over power in Gaza in June 2007. The same could happen in the West Bank where all political, social, economic, education, culture and media institutions (around 200 organisations and centres) have been looted and shut down (Palestinian Information Centre 2007; Hamas 2010).

The use of violence by the PA, as has happened in most Arab states dealing with their oppositions, led and is still leading to the erosion of the firm foundations needed to build a civil state and establish democratic rule.

\section{Feminists engaging with a state instrumentalisation religion}

Regarding the feminist stance, the establishment of the PA in 1993 triggered a process that led to the demobilisation of all social movements, including the women's movement. The most remarkable change occurred with the founding of women's NGOs. Before the formation of the PA, Palestinian society was organised in and around political parties and grassroots mass organisations. NGOs were affiliated with these under the umbrella of the PLO, which encouraged and financially supported the parties and their satellite organisations. While the PLO and its political parties were banned by Israel, their satellite organisations - because they were seen as service providers - were to some extent allowed to function. Women participants in these efforts belonged to what were known as 'grassroots' organisations. These were the women's committees, the branches of political parties, which became so well known for their role in sustaining the first Palestinian intifada in December 1987. Their success lay in organising and mobilising the masses based on their skills in building relations with people. They succeeded because they had a cause to defend and a mission to fulfil and because they believed strongly in the political organisations with which they were affiliated. It was important for them to be known and trusted, to have easy access to people, to care about them and help them when needed. The task required daily, tiring, time-consuming efforts in networking and organising. These cadres knew their constituencies on a personal level and communication depended on face-toface human contact.

By the end of the 1987 intifada, with the signing of the Oslo Agreement in 1993, an early version of the NGO sector was already operating as the main channel for the foreign aid, which enabled service delivery at the grassroots level. These services included clinics, schools, kindergartens and income-generating projects. These NGO actors thus became important and acquired even more power than their parent organisations. When the Madrid Conference initiated the statebuilding process in 1991, the role of NGOs in the West Bank and Gaza changed. There was a noticeable increase in feminist women's organisations from 1988 to 1994 (Jad 2000: 44) propagating a new discourse on women and women's status, but within the context of a steady decline in women's mobilisation. An unpublished study by the Palestinian NGO, Panorama, focusing on five women's mass organisations, shows that membership of these organisations declined by 37 per cent after 1993 and that new enrolment in 1996 did not exceed 3 per cent, with most of it occurring (probably due to patronage) in the Fateh women's organisation (Jad 2000: 44).

The rise in the number and influence of NGOs, on the other hand, which happened alongside the state-building dynamic, cannot be underestimated - if one is to understand the trajectory of the women's movement in Palestine. In fact, the dual dynamics of state building and 'NGO-isation' have led to the increasing fragmentation and demobilisation of all Palestinian social movements. The composition of NGOs has contributed to these 
tendencies: restricted or closed membership; decision-making lying in the hands of the administrative body of the organisation; issues of national concern are transformed into 'projects with limited life cycles; a total dependence on foreign funding, for example. The constituency of NGOs is not a natural social grouping, but artificially constructed. It is receptive rather than interactive and of interest only within the period of a particular project. There is also a cultural dimension, involving the dissemination of values favouring dependency, a lack of selfreliance and new modes of consumption. ${ }^{3}$ NGOisation ( $\mathrm{Jad} 2004)$ as a process has thus introduced changes in the composition of much of the women's movement, bringing to the fore a middle-class, professional women's elite at the expense of the rural and refugee women activists from grassroots organisations. Thus, the reliance of women's NGOs on globalised, rather than local tools, automatically limits the range of possible NGO influence on major issues related to social change such as women's equality and gender justice: hence, their dependence of the 'good will' of the PA to reform the legislation affecting gender relations or to introduce new policies to 'improve' the situation for women.

The political split between the West Bank and the Gaza Strip after Hamas took over power in Gaza on 15 June 2007, left many women's feminist secular organisations in a precarious place. Continuing claiming rights from the PA in the West Bank will mean undermining the power of the Legislative Council paralysed by the political split and the arrest of most Islamist members elected in 2006. It will also encourage the Islamist Hamas government in Gaza to issue its own legislation. Thus, the reliance on issuing presidential decrees to introduce legal reform advocated by women's organisations (particularly in the penal code, issued by presidential decree in March 2010) will lead to limited reform that will apply only in the West Bank and at the expense of democratic institutions and principles. It will also lead to the separation of women's rights from other rights - particularly civil and political rights - violated at many levels by the Palestinian 'secular' authority.

The discourse, therefore, used by some feminist NGOs based on a liberal, individualistic notion of rights, which ignores the plight of many social and political groups and movements deprived by the 'secular' national state from their basic civil and political rights, will not help achieve women's rights (if attempted in separation from other rights) and nor will it help bring about tangible democratic transformation, let alone national liberation.

In this context, the secularists, while pressurising and challenging the Islamists, are nonetheless losing ground by advocating the discourse of rights in isolation from the national agenda and in the absence of organised and mobilised constituencies. Feminist NGO activism, based on short-lived projects, does not have the potential to offer an alternative. By becoming an opposition movement against all forms of violations of civic and human rights, the Islamists have developed a political organisation. In contrast, women in NGOs have no organised constituency and the support they have, if they get it, is derived from a decaying de-legitimised Arab authority.

Amid the stagnant political scene and lack of trust and recognition between secularists and Islamists in the region, there is a way out of the impasse that could forge common ground; the civil state could possibly constitute this common ground. The civil state takes as its basis the idea of the public will vs the divine will, meaning that its source of legitimacy and legislation is this civil will. The civil state is governed by the rule of law and is based on the concept of full citizenship for all its citizens irrespective of race, ethnicity, creed, gender or religion. All citizens are guaranteed civil, political and social rights (women's rights included) by law, as long as strong and well-organised women's movements advocate for their rights. 


\section{Notes}

1 Mostly in the 1950s or post-independence.

2 Efforts to apply the concept of the nationstate to Islam and to the Islamic umma (community of believers) are a salient feature of the recent Muslim exploration of political issues. Some authors have tried to combine Islam with nationalism by treating Islam and Arabism (uruba) as an inseparable entity. AlBazzaz (a young Iraqi teacher), for example, denied there was a contradiction between Islam and Arab Nationalism. For him, Islam is a national religion, the real Islam was Arab Islam and the Arabic language is the 'soul of the Arab Nation'.

\section{References}

Abdel-Jawad, S. (2003) 'The Role of Foreign Forces in Formulating and Promoting Palestinian Elites', paper presented to postgraduate students in the History Department, University of Paris II [in French], 29 April

Abu 'Amr, Z. (1994) Islamic Fundamentalism in the West Bank and Gaza, Bloomington: Indiana University Press

Abul-Omrein, K. (2000) Hamas: Harakat alMoqawameh al-Islameyya fi Falastine [Hamas: The Islamic Resistance Movement in Palestine], Cairo: Marqaz al-Hadara al'Arabeyya [Arab Civilisation Centre]

Al-Azem, S.J. (2004) 'Hamlet wal-Hadatha' [Hamlet and Modernity], a paper presented to al-Hadatha wal Hadatha al-'Arabeyya [Modernity and Arab Modernity] Markaz alDerassat wal-Abhath al-'almaneyya fil al'alam al-'Arabi [Secular Studies and Researches Centre in the Arabic World]

Al-Azmeh, A. (1996) Islams and Modernities, 2nd edn, London: Verso

Anthias, F. and Yuval-Davis, N. (1989) 'Introduction', in F. Anthias and N. Yuval-Davis (eds), WomanNation-State, Basingstoke: Macmillan

Asad, T. (2003) Formation of the Secular: Christianity, Islam, Modernity, Stanford: Stanford University Press

Hamas, The Islamic Resistance Movement (2010) Information Report on the Violations of the Fayyad Illegal Government and its Security Forces in the West Bank during the month of August 2010, www.palestine-info.info/ar/default.aspx? $x y z=$ U6Qq7k\%2bcOd9oXL5mYGoqdoEEylumw4pQ Ww\%2bXLfZ7P (accessed 20 November 2010)

Hermassi, A. (1993) 'Islam, Democracy, and the Challenge of Political Change', in M. Ahrens
3 In advertisements in Palestinian newspapers, it is common to read about collective community actions organised by youth groups, such as cleaning the streets, planting trees, painting walls, etc., followed by a little icon indicating the names of the donors who funded these 'projects'. And many NGO activities are held in fancy hotels, serving fancy food, distributing glossy material and hiring 'presentable' youths to help organise the event. This has led to the gradual disappearance of the 'old' image of the casual activist with the peasant look and accent.

and J. Hilal (eds), Al-Nezam al-seyassi al-falastini ba'd Oslo (The Palestinian Political System after Oslo), Ramallah: Muwatin, Palestinian Institute for the Study of Democracy

Hroub, K. (2000) Hamas Political Thought and Practices, Washington DG: Institute of Palestine Studies

Hroub, K. (1996) Hamas: Al-Fekr wal momarasa alsiyasiyya [Hamas: Ideology and Political Practice], Beirut: Institute for Palestine Studies

Jad, I. (2004) 'The 'NGOisation' of the Arab Women's Movement', IDS Bulletin 35.4

Jad, I. (2000) Palestinian Women: A Status ReportWomen and Politics, Palestine: Bir Zeit University, Women's Studies Institute

Kandiyoti, D. (1998) 'Some Awkward Questions on Women and Modernity in Turkey', in Lila Abu-Lughod (ed.), Remaking Women: Feminism and Modernity in the Middle East, Princeton, NJ: Princeton University Press

Kandiyoti, D. (1991) 'Identity and Its Discontents: Women and the Nation', Millennium Journal of International Studies 20.3: 429-43

Roy, Olivier (1999) The Failure of Political Islam, 2nd edn, Carol Volk (trans), London: I.B. Tauris

Salah, Samira (2003) Interview. Member of the central committee of the Popular Front for the Liberation of Palestine and a leading member of the General Union of Palestinian Women, 8 October, Teheran

Salame, G. (ed.) (2001) Democracy without Democrats? The Renewal of Politics in The Muslim World, London: I.B. Tauris 